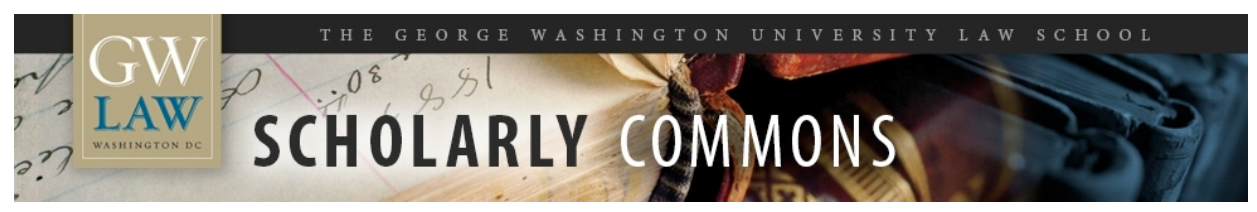

\title{
A Stable Paradigm: Revisiting Capacity, Vulnerability and the Rights Claims of Adolescents after Roper v. Simmons
}

\author{
Catherine J. Ross \\ George Washington University Law School, cross@law.gwu.edu
}

Follow this and additional works at: https://scholarship.law.gwu.edu/faculty_publications

Part of the Law Commons

\section{Recommended Citation}

Catherine J. Ross, A Stable Paradigm: Revisiting Capacity, Vulnerability and the Rights Claims of Adolescents after Roper v. Simmons, in LAW, MIND AND BRAIN 183 (Michael Freeman \& Oliver R. Goodenough eds., 2009).

This Chapter is brought to you for free and open access by the Faculty Scholarship at Scholarly Commons. It has been accepted for inclusion in GW Law Faculty Publications \& Other Works by an authorized administrator of Scholarly Commons. For more information, please contact spagel@law.gwu.edu. 


\section{Law, Mind and Brain}

Edited by

MICHAEL FREEMAN

University College London, UK

and

OLIVER R. GOODENOUGH

Vermont Law School, USA 


\title{
Chapter 8
}

\section{A Stable Paradigm: Revisiting Capacity, Vulnerability and the Rights Claims of Adolescents after Roper v. Simmons}

\author{
Catherine J. Ross'
}

Scientific advances are confirming what parents have long known: the teenage brain is "a very complicated and dynamic area" (National Institute of Mental Health, 2001). When the United States Supreme Court considered the death penalty as applied to crimes committed by a person under the age of 18 in Roper v. Simmons (2005) it received summaries of recent neurological evidence showing that teenage brains are not fully developed. Newly available magnetic resonance imaging (MRI) research, several briefs argued, established that teenagers as a group lack the capacity of the typical adult to make decisions, avoid risks and understand the consequences of their actions and that they are therefore less culpable for violent acts than adults. In Roper the Supreme Court held that persons may not be subjected to capital punishment for crimes they committed between the ages of 16 and 18. Dissenting, Justice Scalia zeroed in on a key analytical problem. He challenged the majority to explain how it is possible to reconcile the view of teenagers as too young to be "treated as adults" when they commit capital offences because they "lack the ability to take moral responsibility for their actions" with the jurisprudence and scholarly literature justifying rights for minors, including the position that adolescent girls are "mature enough to decide whether to obtain an abortion without parental involvement" (Roper v. Simmons, 2005 (Scalia. J., dissenting. p617)).

Framed more broadly, to the extent that the Roper v. Simmons majority reflected awareness of a scientific consensus that teenagers lack the requisite capacity to be held fully accountable for criminal acts, does that finding justify or even mandate a retreat from recognizing classical rights for minors? To answer this fundamental

1 Catherine J. Ross, Yale B.A., Ph.D., J.D., is Professor of Law at George Washington University Law School and. during 2008-9, a Member of the Institute for Advanced Study in Princeton, NJ. The author thanks participants at the interdisciplinary symposium on juvenile justice and brain science held at the Ohio State University Moritz College of Law on 10-11 March 2005 and at the Gruter Institute conference on the brain held February 2006 for comments on earlier drafts, and Dean Frederick Lawrence for his comments and for the generous support of the George Washington Law School. 
question we must ask what the proper relationship ought to be between capacity and rights, vulnerability and voice. On closer examination, I argue, things are not as simple as Justice Scalia proposes they should be.

The second part of this chapter provides a brief summary of the scientific information that has recently emerged as a result of technological advances in the study of the human brain and that was presented to the Court in Roper. The third section reviews the dominant schools of thought about the relationship between capacity and children's legal rights and considers whether emerging scientific knowledge requires a reconsideration of these theories. The fourth section argues that scientific validation of cultural perceptions regarding the vulnerability of adolescents is consistent with theories supporting constitutional rights for minors and indeed supports increased voice and empowerment for teenagers, along with procedural protections that account for their developmental limitations.

\section{Advances in Scientific Understanding of the Teenage Brain}

MRIs allow scientists to study both the structure of the brain and how it functions by non-invasive imaging and provide quantitative data about brain development that was previously unobtainable (Anderson et al., 2006, p2). In 2003 the researchers who developed MRI technology won the Nobel Prize (Anderson et al., 2006). Neuroscientific research on the teenage brain using this new technology provided information to the Supreme Court in 2004 that had not been available when the Court had last considered the application of the death penalty to juveniles in the late 1980s. Although a plurality of the Court had ruled in 1988 that capital punishment for crimes committed when defendants were under the age of 16 constituted cruel and unusual punishment barred by the Eighth Amendment (Thompson v. Oklahoma, 487 U.S. 815,1988 ), the next year the Court refused to bar the death penalty for crimes committed when the defendant was between the ages of 16 and 18 (Stanford v. Kentucky, 492 U.S. 302, 1989).

The very same day it declined to hold the death penalty unconstitutional for acts committed by persons aged 16 to 18 , however, the Court held that the evolving standards of decency implicated by the Eighth Amendment barred the execution of the mentally retarded: their impairments diminish personal culpability, making it "less defensible to impose the death penalty as retribution for past crimes and less likely that the death penalty will have a real deterrent effect" (Roper, 2005, p563, summarizing Penry v. Lynaugh, 492 U.S. 302, 318-20 (1989)). The resemblance between the lack of full capacity demonstrated by teenagers, albeit temporary, and by the mentally retarded, albeit life-long, lent support to the continuing movement to abolish the death penalty for crimes committed by teenagers, no matter how heinous, and strengthened the trend towards abolition cited by Roper as evidence of a growing national consensus that the death penalty is disproportionate when applied to juveniles (Roper, pp564-68). Indeed, in 2003 the Governor of the State of Kentucky commuted the death sentence of Kevin Stanford (the defendant 
whose conviction the Supreme Court had upheld in 1989) on the ground that " $[w] \mathrm{e}$ ought not be executing people who, legally, were children" (Roper. v. Simmons, 2005, p565).

Although no evidence concerning the capacity of adolescents as a group had been presented at the trial or state court appeal (Roper, Transcript of Oral Argument 2004, pp31-34) of Christopher Simmons, a confessed, callous teenage murderer, the Supreme Court received, among other filings, two briefs amicale curiae that presented scientific evidence about the adolescent brain. (Amicae curiae are "friends of the court" who are not parties to an action, but are able to provide information that will be useful to the court's deliberations.) The first brief, submitted by the American Medical Association (AMA) and seven other professional groups, presented evidence from numerous refereed articles in neuroscience and psychology that the behavioural differences between adults and adolescents have an anatomical basis (AMA et al., 2004). A second amicus brief filed on behalf of the American Psychological Association (APA) and the Missouri Psychological Association also summarized recent neuropsychological research as well as an array of behavioural studies from the psychological literature (APA, 2004).

Justice Kennedy's opinion for the Court began his discussion of the nature of adolescence with the comment that "as any parent knows and as the scientific and sociological studies respondent and his amici cite tend to confirm ...." He then summarized the "three general differences between juveniles under 18 and adults" that undermine the "reliability" of determinations that a juvenile is "among the worst offenders" for whom the death penalty is reserved: (i) lack of maturity, impetuousness and recklessness; (ii) special vulnerability to "outside pressure, including peer pressure"; and (iii) the transitory nature of a juvenile's personality traits, which are still in formation (Roper, p569). As Justice Kennedy's prefatory comment suggests, the scientific data before the Court may be more significant for the way in which it bolsters or confirms embedded cultural understandings of development than for paradigm-shifting significance.

One could argue that there is not much new in the notion that teenagers are different from adults. Even the ancient philosophers and Shakespeare identified youth as a stage of life characterized by impulsiveness (consider Romeo and Juliet) and, in Aristotle's terms, unable to understand "moral lectures" (Brooks, 2006, p643). Similarly, the Supreme Court has long weighed youth as a special factor when considering criminal acts committed by teenagers, beginning with the Court's 1932 decision to overturn the conviction of the "Scottsboro boys", black youths who were sentenced to death for raping a white woman, after a trial at which they did not have legal representation (Ross, 1996: Powell v. Alahama. 1932). In 1947 the Court referred to a 15-year-old defendant as "a mere child - an easy victim of the law" who could not be expected to withstand police interrogation, and "cannot be judged by the more exacting standards of maturity ... This is the period of great instability which the crisis of adolescence produces". (Haley v. Ohio, 332 U.S. 596, 1947 p599). 
Although it fits within the rubric the Cour had long acknowledged, the new scholarship on adolescent brain development seems to have influenced the Court (see e.g. Haider, 2006; Denno, 2006) and is often credited as the persuasive evidence leading to the decision in Roper (Gruber \& Yurgelin-Todd. 2006, p331). Concededly, Justice Kennedy's opinion did not cite the neuroscience evidence. perhaps because of issues raised at oral argument about the fact that it had not been tested at trial through cross-examination of the experts (Roper v. Simmons, Transcript, 2004), but his opinion cited liberally to the social science data from the brief's, including articles that, in turn, cited the neuroscience.

Critical findings from MRI research set forth in the amicus briefs included evidence that the dorsal-lateral frontal lobe of the brain, which handles "judgments and values, long-term goals, the weighing of risks and consequences - what parents call wisdom or common sense and what science calls "executive function"." (Williamson. 2005) is among the last areas of the brain to mature, and does not reach full maturity until well after the age of 18 (AMA, 2004. p16, 16 n. 55, citing authorities). Another line of research documented that teens process emotions differently than adults, in distinct areas of the brain (Williamson, 2005). Teenagers process a great deal of intormation in the amygdala. which, according to the AMA's brief, "is associated with aggressive and impulsive behavior" and "dictates instinctive gut reactions" in comparison with the frontal lobes, which handle "'more complex" information-processing functions" including "thinking" and "reasoning" (pp25, 26).

As teens grow older, brain activity tasks tend to shift gradually to the frontal lobe and communication between the frontal lobe and the amygdala improves (AMA, 2004, pl5), reflecting increased reliance on reasoning rather than emotion, more reasoned perceptions, and improved performance of tasks and life skills. The evidence makes clear that "[o]ne of the last areas of the brain to reach full maturity $\therefore$ is the part associated with regulating behavior, stifling impulses, assessing risks, and moral reasoning" (AMA, 2004, p20). And, this process may last into the early to mid-twenties (Arshagouni, 2004, p35I), long past the age at which the laws of various states allow young people to marry, vote, drink or drive (Roper, 2005, Appendices).

As exciting as it is to view the brain at work through MRIs, the new data are entirely consistent with longstanding legal presumptions about youth. Throughout the twentieth century Supreme Court decisions about the young expressly proceeded from an understanding that young people are different from adults (Ross, 1996) as did the rulings that captured the rehabilitative vision of the juvenile justice system (Ross, 1995). Contemporary scholarship on juvenile justice emphasizes knowledge of child development as being essential to best practices (Scott \& Steinberg, 2003; Scott \& Grisso, 1997) in stark contrast to the mounting trend in state courts and federal legislation to treat juvenile offenders as adults (Johnson et al., 2004).

The new data from brain imaging are, however, critically important to the broader debate about the accountability of juveniles within the justice system in at least one respect: they establish that an individual teenager is not responsible 
for an inability to exercise certain kinds of self-control or to reflect upon the consequences of actions. Scientific research points to neurological bases for the impulsivity and shortsightedness that predominates among adolescents. It suggests that a teenager's failure to consider consequences does not lie in personal deficiencies but is attributable, at least in part, to neurobiology, beyond the control of any typical individual. This analysis, which led to a categorical ban on capital punishment for crimes committed by teenagers. may also be extended to support a distinction between moral culpability and legal accountability that results in harsh. inflexible legal punishment for lesser offences. This sort of extension would be comparable to the Court's adjustment of its initial line-drawing for accountability for death penalty purposes from 16 (Stunford v. Kentucky, 1989) to 18 as the Court in Roper.

One of the issues on which the Roper majority and the dissenters differed was the question of whether individualized consideration of the defendant's maturity by the jury was a sufficient safeguard against the unjust execution of any particular person who committed a heinous act. The Justices disagreed about the implications of the evidence presented in the briefs showing that most persons under the age of 18 do not have the capacity to be held fully accountable under law for their crimes (compare Roper, pp572-73 to p588, p618, 620). Justice Scalia framed the issue by stark contrast of the death penalty cases to the Court's rulings in the context of abortion, in which the APA had submitted an amicus brief arguing that "[b]y middle adolescence" minors "are mature enough to decide whether to obtain an abortion without parental involvement" (Roper, 2005, p617 (Scalia, J. dissenting), quoting APA, 1989, p18 in Hodgson v. Minnesota, 1990). How, Justice Scalia asked, can a minor be mature enough to obtain an abortion without parental consent but not mature enough to be held accountable for a heinous murder: "Whether to obtain an abortion." he posits, "is surely a much more complex decision for a young person than whether to kill an innocent person in cold blood" (Roper, 2005, p620).

The simple answer to Justice Scalia's challenge is that the Court's jurisprudence on abortion rights for minors presumes, first, that most minors will consult their parents, and that only a small group of girls who feel they cannot do so will need to avail themselves of the procedural rights the Constitution guarantees. The Court has held that no state may require that a minor receive parental consent to obtain an abortion unless the state provides a judicial framework in which a judge may substitute her consent for that of the parent (known as a "judicial bypass" procedure) (Bellotri v. Baird. 1979; Hodgson v. Minnesota, 1990). Properly understood, a minor's right to abortion involves substitution of one adult's supervisory power (the judge's) for another's (the parenl's). A bypass hearing requires a judge to ask two questions. First, is the particular minor seeking an abortion "mature" enough to understand the decision? If so, the judge should consent to the abortion. If not, the judge reaches the second question: is it in the minor's best interests to have the abortion? Given that the judge has already determined that the girl is too immature to make the decision to abort herself. she is presumably too immature to have and raise a baby. In neither event is the girl treated as fully mature and independently accountable. 
One immediate distinction between abortion and imposition of the death penalty involves the impact of the two decisions on the young person's future. It is generally agreed that the primary justification for paternalism toward the young is that adults will try to make wise decisions that serve the child's best interests by preserving the child's options in life. For example, the state may intervene where a child's parents or guardians withhold life-preserving medical treatment, engage in abusive behaviour that threatens the child's physical or emotional health, or withhold education.

In the context of abortion, as Justice Powell cogently observed, "the potentially severe detrinient facing a pregnant woman [citation omitted] is not mitigated by her minority. Indeed, considering her probable education, employment skills, financial resources, and emotional maturity, unwanted motherhood may be exceptionally burdensome for a ninor" (Bellotti v. Baird. 1979, p642, quoted in Hodgson v. Minnesota, 1990, p434). Indeed, having a baby effectively terminates the teenage girl's adolescence and propels her, prepared or not, into adulthood (Bellotti v. Baird, 1979, p642). Because the consequences of childbirth are potentially so farreaching, the option of abortion must be available to teenagers who seek it in order to preserve their options in life. The contrast to the imposition of the death penalty could not be starker: it goes without saying that the death penalty terminates life itself. while alternative harsh penalties such as life imprisonment effectively diminish the quality of life (and render many or most options unavailing) but does not completely extinguish it.

The Supreme Court's conclusion in the abortion context "that a minor may be very much an adult in some respects does not mean that his or her need and opportunity forgrowth under parental guidance and discipline have ended" (Bellotti v. Buird, 1979, p644) is confirmed by recent social science as well as neuroscience. Furstenberg et al. (2004) have documented that the transition from adolescence to adulthood, measured by life events such as completing education, becoming self-supporting and developing a clear sense of self takes much longer today than it did in 1900 or even in 1960 . They estimate that the period of transitional, or incomplete, adulthood lasts into the thirties for more than two-thirds of men, and into the late twenties for three-quarters of women.

Arguably Justice Scalia's challenge was more in the nature of a debater's dismissive quick jab than a weighty question, for it implies a reductionist portrait of the arguments on behalf of rights for minors. It is, however, worth exploring whether Roper poses a serious challenge for advocates of children's legal rights. The remainder of this chapter considers the implications of the emerging knowledge about the teenage brain for competing theories of children's rights.

\section{Theories of Children's Rights}

The inherent tension between children's vulnerability and voice has been a central theme in academic discussions of children's rights, particularly in the United States. 
The philosophical rension is less pronounced among the other nations, all of which. with the exception of Somalia, have undertaken to comply with the United Nations Convention on the Rights of the Child (1989). The UN Convention incorporates provisions that recognize children's vulnerabilities (e.g., the right to education, housing. health services and other needs-based services and to be protected from abuse and exploitation, generally referred to as "welfare rights") side by side with articles that guarantee civil and political rights for minors (e.g., the right to be heard in matters affecting them, freedom of thought, speech and religion) (UN Convention, 1989; see also Buck, 2005). Of course, many signatories do not in fact provide either set of rights, but that set of problems is beyond the scope of this chapter.

The Convention's organizing principles embrace the notion that the view of children as having needs is entirely compatible with the position that they have rights as defined by the liberal political tradition. Under this view, Justice Scalia's challenge to children's advocates might be a non-starter. But in the United States, and perhaps elsewhere, it appears essential to explain how we may reconcile the acknowledged vulnerabilities of minors with rights claims.

In light of the interdisciplinary nature of this volume, this section briefly introduces the major schools of thought regarding the relationship between children's level of competency and their claims to both kinds of rights recognized by the UN Convention. The literature can be roughly divided into four schools of thought. with the caveat that three of the four schools may not be mutually exclusive: (i) the nurturance model: (ii) the "liberationist" model; (iii) the classic "rights model" applied to minors; and (iv) the "empowerment" model. Each of these models, discussed in more detail below, requires distinctions among sub-groups of minors delineated by factors including age and capacity. With the exception of the liberationists, all have attempted to account for the ways in which children and teenagers differ from adults, have accordingly proposed sliding scales of rights, and have considered the distinctions that arise based on the varying contexts in which rights and interests may be asserted.

\section{The Right to Nurture}

Who can seriously argue that children do not need to be nurtured? As Woodhouse's (1993) classic article underscores, the starting point for discussions of children in legal systems is children's dependency and vulnerability. The issue is how we respond to that dependency - which for infants is literally a matter of life and death. Woodhouse proposed what she called a "generist perspective" in which both private stewardship (parenthood) and communal responsibility for children would be evaluated based on how well they fulfil their obligations to the next generation in contrast with the current emphasis in the United States on the rights of biological parents. The concept that children require essential care is embodied both in laws allowing states to intervene to prevent child abuse and in the welfarist provisions of the UN Convention. Children are distinguished by their "double dependency 
on parents and on the state" (Minow, 1986, p24). Since children are not just miniadults, such laws and covenants are designed to protect their "development rights" - the rights that allow them to achieve their potential (Minow, 1995). Whether a society can mandate loving parents - which the psychological sciences argue are necessary to healthy development (Goldstein et al., 1996) - is more controversial (Ross, 2006a).

David Archard (2004) suggests that children have what he terms "moral rights", including rights available only to children and resting on their special status as children. Such rights, however, having their origin in communal ideals, become more than moral exhortation and are transformed into legal rights when the state establishes a floor beneath which the standard of care accorded children by their legal guardians may not fall without endangering the terms and existence of the guardianship. Where each society draws that line, how the line is enforced, by whom and how successfully are critical questions that lie beyond the scope of this chapter.

In a similarvein, Minow (1990) and others have emphasized the interdependency of family members rather than giving primacy to the individual rights claims of family members. This view suggests that the neediest in the family (the children, or those with disabilities rendering them vulnerable) receive the attention and support they need even at cost to the caregivers. The obligation flows from the adult to the child as a matter of responsibility, without any legally implied reciprocity or reward. The Scotts (1995) go one step further, positing that parents may be regarded as having a legally enforceable fiduciary duty to care for their offspring.

With the possible (and wholly theoretical) exception of radical liberationists, all advocates for children and their rights presumably adopt the precepts of the nurturance school. The question is how much we want to add to it, the content of those additional arguments, and when certain rights or claims should be triggered.

\section{The Liberationist Model}

This approach, entirely attributable to social scientists and largely related to the broader social trends of the 1960 s, took the view that families and other authoritarian structures oppressed children. Children, its proponents argued, should be accorded all of the legal rights held by adults, including the right to self-determination (Archard, 2004). Since none of the leading children's liberation theorists (Holt, 1974; Farson, 1974; Neill \& Fromm, 1960) were legal scholars, it may not even be necessary to acknowledge liberationists as a serious school of legal thought about children and rights. To the extent that we take liberationists at face value, if they mean that children of all ages should be left to their own devices, recognition that children need caretaking diminishes, and the emerging scientific evidence about the brain would seem to demolish, the school's legitimacy. 


\title{
The Liberal Rights Model
}

A third school of thought, while recognizing that children need nurturance, argues that children should nonetheless share in the classical Jiberal rights available to adults in their society. In the United States, this view has prevailed at least in part in Supreme Court decisions such as In re Gatlt (1967), which established a minor's right to counsel, adequate notice; confrontation and cross-examination of witnesses and freedom from self-incrimination in proceedings that might result in confinement, and Tinker v. Des Moines Independent Community School District (1969), frequently cited for the proposition that "[i]t can hardly be argued that students or teachers shed their constitutional rights to freedom of speech or religion at the schoolhouse gate" ( 5506 ), implying that students, who are presumably minors, share in such rights.

None of these cases suggest, however, that the rights of minors are co-extensive with those of adults, and indeed the Court has expressly stated they are not:

\begin{abstract}
Viewed together, our cases show that although children generally are protected by the same governmental guarantees against governmental deprivations as are adults, the Staie is entitled to adjust its legal system to account for their vulnerability ... These rulings have been grounded in the recognition that, during the formative years of childhood and adolescence, minors often lack the experience, perspective and judgment to recognize and avoid choices that could be detrimental to them (Bellotii v. Baird, 1979, p635).
\end{abstract}

From this perspective, the new science about the adolescent brain may be viewed as merely confirming what the Court already understood and integrated into its vision of children's rights: a scaled version of adult constitutional rights, adjusted for minors - and generally restricted to teenagers.

The autonomy rights of minors may be constrained by the state's deference to the views of their parents and guardians in matters such as freedom of speech, receipt of information and religious exercise (Ross, 1999). Whether or not these restrictions are justified may depend on such factors as the child's age (two or seventeen), the context in which the minor wishes to assert independence and the nature of the perceived risks. Indeed, the ability of minors to assert their rights generally depends on the support of the adults who have responsibility for them.

This brings us to the question of capacity that lies at the heart of Justice Scalia's challenge to children's rights advocates. If adolescents are characterized by diminished capacity to make reasoned choices, can they still claim classical rights on their own behalf? Archard (2004) identifies three components of rational autonomy that are generally regarded as a precondition to the exercise of rights: "rationality, maturity and independence". The evidence from neuroscience would seem to undermine the pure autonomy claims of minors in that the parts of the brain related to rational decision-making and other behaviours our society associates 
with maturity appear not to be fully functional in teenagers. If rationality requires cognitive competence, the science underscores that teenagers, as a group, lack it.

As Archard (2004) and others argue, however, many adults also fall short of J.S. Mill's idealized prudent and rational citizen and are nonetheless allowed to exercise rights of self-determination. Moreover, in most instances the state does not categorically bar people over the age of 70 or 80 from driving, voting, working or living independently. Since independence (if defined as independent living and financial self-sufficiency) comes later and later for the young, independence premised on competency might be regarded as a shrinking stage of life. But we might also ask who in the modern world is truly independent and self-sufficient?

Limitations on the affirmative civil rights of minors (such as the right to express political views at school in a non-disruptive manner recognized in Tinker). based on arguments that young people are not yet fully cogent. must presumably be based on arguments that parallel the justifications for paternalistic protections of the sort discussed above. That is, for any argument in support of limiting rights to succeed under this model it would need to rest on the notion that exercise of certain rights now would ultimately diminish the range of choices available to the child in the future.

Taken to its outer edge, the rights model would seem to require granting suffrage to minors, since the vote is the critical recognition of citizenship. I am unaware of any legal commentator who has proposed that all children be able to vote, though many observe that some minors may be far better qualified to vote (by virtue of interest in and information about politics) than some adults who have the privilege, including the illiterate, the uninterested and those who fail to exercise their franchise. Archard (2004) observes that people may vote at age 16 in several countries, and argues that teenagers are capable of exercising the franchise.

So too I am unaware of any scholar who has argued that small children lacking in capacity should be able to exercise independent liberty claims vis $a$ vis the state. Instead, the portrait of a school of thought premised on the assumption that capacity is irrelevant seems to flower in the assertions of those who criticize granting legal standing and authority to the young. Buss (1999), for example, challenges lawyers for children to show greater awareness of socio-cognitive development. Certainly incorporating longstanding knowledge of child development into legal theories has been critical from the earliest days (e.g., Wald, 1979), and it will now be complemented by new knowledge about the brain, much of which confirms what we long knew or suspected from observation. Buss's comments were largely directed at proponents of empowerment, within the context of litigation. particularly proceedings arising out of abuse and neglect. The next section considers the empowerment approach to children's rights in a broader context.

\section{Empowerment}

The empowerment perspective shares with the caretaking approach an acceptance of children's developmental dependency, especially in the early years, and their 
needs for nurturance. It shares with the classical liberal model a recognition that rights have "intrinsic worth" (Federle, 1995, p1595) because once rights are recognized those who would intrude on those rights must, at a minimum, justify the intrusion, and/or take the rights-holder's perspective into account. Federle (1995) has correctly identified capacity as a central dilemma for this approach. To the extent that classical liberal theories of rights demand that rights-holders satisfy the requirement of capacity (as discussed above), presumptively established by achieving a certain birthday ( 18 or 21 ), how do children successfully claim rights? Federle, for example, rejects delegation of children's rights to adults standing as their proxies, because, in her words, "a caretaker ideology ... promotes the powerlessness of children" (p1590). The implications are practical as well as symbolic. The very adults who would normally stand as proxies for minors (their parents and guardians) may be the adults who stand between children and their rights as in the context of abortion, unwarranted psychiatric hospitalization or independent religious expression (Ross, 1996, 1999). Or, even if parents are well intentioned and share their children's goals, they may not be the most capable representatives of their children's interests (Ross, 1996).

Empowerment means the right to be heard about important decisions in the public sphere that affect a child's future, whether directly or through a representative who presents the child's viewpoint (Ross, 2006). Proponents of this approach may differ on the extent to which the child's ability to formulate and articuiate their views matters, and the extent to which such ability tracks normative definitions of capacity. But they tend to emphasize that participation in process protects rights and assuages the sting of powerlessness even if the ultimate decision does not conform to the child's expressed preferences.

Because the leading theorists of children rights - whether from the caretaking, classical liberty or empowerment approaches - recognize that children are not the same as adults in critical respects related to capacity and competency, the new science does not seem to call for the paradigm shifts Justice Scalia envisions. Brain imaging may, however, bolster arguments for children's rights based on rather than in spite of - the vulnerabilities and analytical deficiencies of the young, as discussed in the next section.

\section{A Strengthened Paradigm}

With the pronounced exception of the liberationists, doctrinal debates about the rights of minors have already taken into account a presumed lack of capacity and the very gradual nature of maturation. Brain imaging underpins this understanding with science, but for purposes of legal analysis at most it calls merely for recalibration, not paradigm shifts.

By giving a physiological basis to some of the indicia of immaturity in teenagers, however, the new findings accentuate three features of what we may broadly term lack of fully developed capacity. First, for teenagers as a group the 
capacity to make reasoned decisions may not be readily amenable to increased logic and information to the extent that the brain is not equipped to process that information. This is perhaps a starker statement than reflected in some of the legal literature to date. Second. the research suggests peaks and valleys in development rather than a linear progression. Third, while we have always acknowledged that 18 is merely a heuristic bright line the research suggests that as a physiological matter adolescence extends far beyond the age of 18 .

Finally, brain MRIs mesh with the notion of youth as a "stage" which we all pass through. Scientist Jay Giedd reminds us that teenage brains are not broken, they are just under construction (Williamson, 2005). This generality is not disqualifying under any of the rights models because adults are not uniformly graced with capacity. Proponents of empowerment have always reminded their critics that adults who do not appear to think rationally or make choices others think wise nonetheless receive the full panoply of legal rights. The notion of the teenage brain as being in formation also supports the advocates of rights as caretaking and the importance of relational rights highlighted by feminist scholars.

Acknowledgement of teenagers' limited capacity does not necessarily support diminishment of their rights, because vulnerability and voice are not always diametrically opposed. Instead of treating vulnerability and rights as mutually exclusive, the vulnerability of young people can be turned to their advantage and used to bolster their rights claims (Ross, 1996). In several contexts, children's vulnerabilities may justify expanding rights and procedural protections rather than constricting them. To the extent that maturing minors lack the full executive functioning usually associated with complete autonomy, MRI discoveries about the adolescent brain may support expansion of rights designed to protect the vulnerable, particularly in court proceedings. Consider, for example, the adolescent's need in some circumstances, for appointed counsel in civil litigation, and, more frequently. for adult guidance and other special protections in navigating the justice system.

Children's vulnerabilities may in some instances argue for expanding their rights, for example by building on the parallels between the incapacities normatively associated with childhood and the situations in which courts appoint counsel for pro se litigants such as prisoners in civil litigation (Ross, 1996). Federal courts in the United States have the discretion to appoint counsel in civil cases, though it is rarely exercised outside the context of petitions from prisoners. whose lack of autonomy while incarcerated may resemble the position of minors in some authoritarian families, or at least the teenager's perception of the limits on their autonomy. Judges considering applications for counsel generally look to such factors as lack of financial resources, the merits of the claim, and the applicant's "ability to investigate the crucial facts ... ability to present the case [and] the complexity of the legal issues" bearing in mind issues such as the level of education attained, maturity and judgment, all of which would favour making counsel available to teenagers based on their common analytical deficits. (Ross, 1996 p 1598). MRI findings also bolster the argument that where teenagers or courts perceive that parents are not appropriate spokespersons for their children 
(for example, where children are committed to psychiatric hospitals over their objections) or their interests conflict with their parents" choices in other ways (Ross. 1999) or children in foster care whose parents are not presumed to speak for them (Ross, 2006), courts should appoint counsel to help young people tell their stories.

Similarly, I have argued that although "children's vulnerability is commonly used to justify state paternalism rather than to promote rights for minors" (Ross, 2003, p86) recognition of the cognitive and experiential limitations of minors should support zealous protection of their procedural rights. In particular, I have argued that a parent-child evidentiary privilege (which is not currently recognized under federal law or in more than a handful of states) is necessary so (hat parents may serve as conduits for their children's assertion of rights in court proceedings. How can teenagers solicit their parents' guidance about such issues as whether to waive their right to appointed counsel, or ask their parents to invest in private counsel without telling their parents what really happened in the activities leading up to the court appearance?

In contrast to most or all of Europe (Ross, 2003). under current law in the United States when a parent asks "what happened", the parent is at risk of being called as a witness against their own child. So too, parents might not urge children to "tell the truth" to police officers, as they frequently do, if they knew what the child was about to say. Psychological research, now supported by brain MRIs. indicates that the young are particularly vulnerable during interrogations (Grisso, 2006) and need help with the critical decisions made in the course of a trial, including whether to accept a plea bargain. To the extent that parents and children share the same goals in a child's court proceeding, a parent's advice and mediation of the judicial system may be the most effective means of preserving a child's procedural rights, and will undoubtedly be more elfective if the child is assured that their confidences to a parent are protected by law. It is perverse to recognize the vulnerability of children on the one hand, and to acknowledge that children have constitutional rights with the other, without recognizing how the vulnerabilities of youth may diminish the exercise of rights and then to take responsive measures.

In Roper, amici APA argued that the MRI studies and other new data demonstrate that "adolescent immaturity undermines a defendant's ability to make meaning ful and fully informed decisions to manage his or her own definse" (APA. 20()4. p23). Teenagers need special protections because they cannot effectively navigate the justice system on their own, and must confide in their parents to get meaningful advice. Similarly, emerging knowledge about the teenage brain arid its role in impulsivity and difficulty resisting collective wrongdoing reinlores authoritative arguments against the trend in the United States to try and sentence teenagers as young as age 13 in adult courts and even to incarcerate them with adults (sie' Campaign for Youth Justice. 2007; Corriero, 21)(06; Zimring 1998).

The hard science supports what we have long observed, and cautions us to remember that immaturity disadvantages youth at every stage from committing an offence through trial. sentencing and punishment. It also may help us, as a 
community, to anticipate and meet children's needs in the first instance, and, when some young people get off track, to acknowledge and facilitate the rehabilitative possibilities that exist for many individuals. In such a world, when their brains finally mature, the young may still be in a position to realize life's possibilities.

\section{References}

American Medical Association et al. 2004. Brief of the American Medical Association [et al.]... as Amici Curiae in Support of Respondent, Roper v. Simmons, No. 03-633.

American Psychological Association \& the Missouri Psychological Association. 2004. Brief for the American Psychological Association and the Missouri Psychological Association as Amici Curice Supporting Respondent, Roper v. Simmons, No. 03-633.

American Psychological Association. 1989. Brief for the American Psychological Association as Amicus Curiae Supporting Petitioner/Cross-Repondent, Hodgson v. Minnesota, No. 88-805.

Anderson, D.R. et al. 2006. Brain lmaging - An Introduction to a New Approach to Studying Media Processes and Effects. Media Psychology 1-6.

Archard, D. 2004. Children, Rights and Childhood. 2d ed. Routledge: London.

Arshagouni, P. 2004. "But l'm an Adult Now ... Sort of": Adolescent Consent in Health Care Decision-Making and the Adolescent Brain, 9 J. of Health Care Law and Policy 315.

Brooks, R.O. 2006. "The Refurbishing": Reflections Upon Law and Justice Among the Stages of Life, 54 Buffalo L. Rev. 619-692.

Buck, T. 2005. International Child Law. London: Cavendish Publishing Lid.

Buss, E. 1999. Confronting Developmental Barriers to the Empowerment of Child Clients, 84 Comell L. Rev. 895.

Campaign for Youth Justice. 2007. The Consequences Aren't Minor: The Impact of Trying Youth as Adults and Strategies for Reform.

Corriero, M.A. 2006. Judging Children as Children: A Proposal for a Juvenile Justice System. Philadelphia: Temple University Press.

Denno, D.W. 2006. The Scientific Shortcomings of Roper v. Simmons, 3 Ohio State Journal of Criminal Law, 379-396.

Farson, R. 1974. Birthrights. London: Collier, MacMillan.

Furstenberg, F.F., Jr. et al. 2004. Growing Up Is Harder to Do, 3 Contexts: Understanding People in Their Social Worlds 1. http://www.contextsmagazine. org/content-sample-v3-3.php.

Goldstein, J., Solnit, A.J., Goldstein, S. \& Freud, A. 1996. The Best Interests of the Child: The Least Detrimental Alternative. New York: The Free Press.

Gruber, S.A. \& Yurgelin-Todd, D.A. 2006. Neurobiology and the Law: A Role in Juvenile Justice?, 3 Ohio State J. of Criminal Law, 321-340. 
Haider, Aliya, 2006. Roper v. Simmons: The Role of the Science Brief. 3 Ohio

State Journal of Criminal Law 369, 369-377.

Haley' v. Ohio, 332 U.S. 596 (1947).

Hodgson v. Minnesota. 1990. 497 U.S. 417.

Holt, J. 1974. Escape From Childhood: The Needs and Rights of Children. Harmondsworth: Penguin.

In re Gault. 1967.387 U.S. I.

Johnson, D.L. et al. 2004. The Violent Youth Offender and Juvenile Transfer to the Adult Criminal Court. 2004 Journal of the Institute of Justice and International Studies 84.

Minow, M. 1995. What Ever Happened to Chldren's Rights? 80 Minnesota Law Review 267.

Minow. M. 1990. Making All the Difference: Inclusion, Exclusion and American Law. Ithaca: Comell University Press.

Minow, M. 1986. Rights for the Next Generation: A Feminist Approach to Children's Rights. 9 Harvard Women's Law Journal 1.

National Institute of Mental Health. 200l. Teenage Brain: A Work in Progress. Available at http://www. Nimh.nih.gov/pubcat/teenbrain.cfm. (last visited 21 June 2007).

Neill, A.S. \& Fromm, E. 1960. Summerhill: A Radical Approach to Child Rearing. Harmondsworth: Penguin.

Penry v. Lynaugh. 1989.492 U.S. 302.

Pow'ell v: Alabama, 287 U.S. 45 (1932).

Roper v. Simmons. 2005. 543 U.S. 551.

Roper. v. Simmons, 2004. . Transcript of Oral Argument, October 13. 2004. 2004 U.S. Trans LEXIS 55.

Ross, C.J: 2006. A Place at the Table: Creating Presence and Voice for Teenagers in Dependency Hearings. 6 Nev. L. J. 1362.

Ross, C.J. 2006a. Review of James Dwyer's The Relationship Rights of Children, 16 Law and Politics Book Review 975.

Ross, C.J. 2003. Implementing Constitutional Rights for Juveniles: The ParentChild Privilege in Context. 14 Stanford Law \& Policy Review 85.

Ross. C.J. 1999. An Emerging Right for Mature Minors to Receive Information. 2 U. Pa. J. Const. L. 223.

Ross, C.J. 1996. From Vulnerability to Voice: Appointing Counsel for Children in Civil Litigation, 64 Fordham Law Review, 1571-1620.

Ross. C.J. 1995. Disposition in a Discretionary Regime: Punishment and Rehabilitation in the Juvenile Justice System. 36 Boston College Law Review 1037.

Scott, E. \& Grisso. T. 1997. The Evolution of Adolescence: A Developmental Perspective on Juvenile Reform. 88 The Journal of Criminal Law and Criminology 137.

Scott, E. \& Steinberg, L. 2003. Essay: Blaming Youth. 81 Texas Law Review 799. 
Scott, E.S. \& Scott, R.E.1995. Parents as Fiduciaries, 81 Va. L. Rev. 2401. Stunford v. Kentucky. 1989. 492 U.S. 302.

Thompson v. Oklahoma, 487 U.S. 815, 1988.

Tinker v. Des Moines Indep. Community Sch. Dist. 1969. 393 U.S. 503.

United Nations. 1989. Convention on the Rights of the Child.

Wald, M. 1979. Children's Rights: A Framework for Analysis? 12 U.C. Davis L. Rev. 255.

Williamson, E. 2005. Brain Immaturity Could Explain Teen Crash Rate; Risky Behavior Diminishes At Age 25. The Washington Post. Feb. 1. A-1

Woodhouse, B.B. 1993. Hatching the Egg: A Child-Centered Perspective on Children's Rights, 14 Cardozo L.Rev. 1747.

Zimring. F. 1998. American Youth Violence. New York: Oxford University Press. 